\title{
Environmental Impact of Land-use Changes and Soil Loss on Coastal Coral Reef Cover: Study Case in the Small Tropical Island, Indonesia
}

\section{Asep Mulyono ( $\sim$ asepliwa@yahoo.co.id )}

Indonesian Institute of Sciences: Lembaga Ilmu Pengetahuan Indonesia https://orcid.org/0000-00015999-4247

\section{Muhammad Rahman Djuwansah}

Indonesian Institute of Sciences: Lembaga Ilmu Pengetahuan Indonesia

Ida Narulita

Indonesian Institute of Sciences: Lembaga Ilmu Pengetahuan Indonesia

\section{Risandi Dwirama Putra}

Universitas Maritim Raja Ali Haji

Dewi Surinati

Indonesian Institute of Sciences: Lembaga Ilmu Pengetahuan Indonesia

\section{Research}

Keywords: Land-use change, soil loss, coral reef, coastal, Bintan island

Posted Date: January 19th, 2021

DOI: https://doi.org/10.21203/rs.3.rs-148449/v1

License: (c) (1) This work is licensed under a Creative Commons Attribution 4.0 International License. Read Full License 


\section{Abstract}

Over $24 \%$ of coral reefs in Southeast Asia, including Indonesia, experience damage from development in coastal areas by coastal construction, land conversion, beach nourishment, and port construction. The rapid economic development activities around the coast of Bintan Island impact the extraction of natural resources and reduction of the coral reefs cover. A comprehensive study to determine the temporal change in land use and estimate the rate of soil loss and its effects on coral reef cover is needed. There has been a change in land use for five years (2014-2018) on the east coast of Bintan Island, and the average percentage of coral reef cover is in the fair category $(<50 \%)$. The land-use changes have resulted in soil loss that varies each year. Apart from land-use changes, the factor of rainfall is one of the causes of soil loss. Soil loss is generated from cultivated lands due to the lack of conservation techniques. In east Bintan island, mixed garden, plantation, and bare land area with dense canopy cover contributed increasing of soil loss. The contribution of soil loss to hard coral reefs as a result of land use changes from high to low is soil erosion > soil sediment > surface run-off.

\section{Introduction}

Coastal development, land reclamation, beach nourishment, and touris area construction, all of which involve dredging, are increasingly required to meet the growing economic and societal demands in the coastal zone worldwide. In tropical regions, many shorelines are home to people and coral reefs, one of the most biodiverse ecosystems on earth [1]. 25\% of coral reefs in Southeast Asia, including Indonesia, are threatened by development in coastal areas, and $21 \%$ by sedimentation and pollution from land [2]. In Indonesia, the prevalence of pollutants on nearshore coral reefs caused by Domestic and industrial runoff, nutrients, sewage, pesticides, tributyltin/TBT [3].

Several studies on the impact of the environment on coral reefs have been carried out, one of which is documenting the condition of coral reefs from the aspects of land-based pollutants [4], hydrological processes, and the transport of pollutants from land to coral reefs [5], distribution of nutrients from land and sediment [6] and applied conservation scheme also overcome barriers to joint land-coastal policymaking [7]. Several types of pollutants that damage coral reefs' condition are sediment, nutrients, pesticides, heavy metals, industrial and pharmaceutical contaminants [8].

Bintan Island is one of the small islands in the Riau archipelago, Indonesia. This island was very well known in its time as a bauxite mining island. The extent of former bauxite mining on the isle leaves excavated land where vegetation regrowth poorly due to the soils' limited natural fertility. The rapid economic development activities around the coastal and marine areas of Bintan Island impact the extraction of natural resources and pollution of the coastal and marine environment, especially coral reefs. The coral reef ecosystem in Bintan Regency has long been able to improve the community's economy and the area through fishing locations and marine tourism. However, mining activities for bauxite, granite, and inland sand have harmed coral reefs' growth. 
The eroded sediment has contributed to eutrophication downstream and coastal in Bintan Island. In the past decade, soil erosion has severely occurred in Bintan Island, as evidenced by the extend of converted land, which has been cleared following deforestation in the basin [9]. The expansion of critical land continues to grow along with the population growth and the rapid development of infrastructure on the island. Eutrophication problems have occurred in Bintan Island's coastal waters with the emergence of phytoplankton blooms [10]. The seagrass beds damage in the coastal area of Bintan Island is caused by mud due to sedimentation. The number of suspended sediments in the coastal was positively related to the phytoplankton concentrations [11]. Total organic material and total suspended sediment in Bintan Island's river and coastal waters above the quality standard [12] have affected the nearshore of coral-reef ecosystems.

It lacks information about land-use change and soil loss factors on coral reefs on the coast of Bintan Island. Land use planning in coastal areas without integrating land-based controls can be prone to pollution in coastal areas $[13,14]$. This study aims to determine the temporal change in land use and estimate the rate of soil loss and its effects on coral reef cover. Evaluation of changes in land conditions and loss of land in the coastal area of Bintan island helps planning for conservation and rehabilitation of the area to be more integrated, right on target, and measurable.

\section{Materials And Methods \\ 2.1. Study area}

The study site is located at four sub-watershed areas in the East Coastal of Bintan Island, Riau Islands province (Fig. 1). The geology comprises sedimentary formations Pre-Tertiary and Quarter and igneous rocks, consisting of granite and diorite [15].

The soil types were Acrisols, Cambisols, and Podzols [16]. The islands' topography is dominantly undulating land with hillocks where slopes varied from $0-3 \%$ in the flat region to above $40 \%$ in the hilly areas. The rivers are generally short, shallow, and not wide. The largest watershed in Bintan island is the Jago watershed covering $135.8 \mathrm{~km}^{2}$, followed by the Kawal watershed covering $93.0 \mathrm{~km}^{2}$.

The average temperature ranges from $26.1-26.7^{\circ} \mathrm{C}$, and the average air humidity range from $70-95 \%$. The rainy season occurs twice a year. May and December generally receive the highest annual rainfall while the lowest rainfall fall in August. During the rainy season, the monthly rainfall is about 200$390 \mathrm{~mm}$, and in the dry season, the monthly rainfall is about $170 \mathrm{~mm}$. Assuming that dry mouth is the month when precipitation is less than $80 \mathrm{~mm}$, there is no real dry month in Bintan Island's average monthly rain.

\subsection{Data analysis}

Land use/cover map was identified by a supervised digital image classification method with a resolution of $30 \times 30 \mathrm{~m}$. It was used as the main data source from five different periods (2014-2018). The land use 
analysis is carried out to assess the land-use changes each year. Hard coral reef conditions data during the 2014-2018 period was obtained from COREMAP-CTI data at three observation stations (Fig. 1) in the East Coastal of Bintan Island.

Soil loss prediction (2014-2018) using the soil and water assessment tool (SWAT) [17] model requires data information of topography, drainage network, land use, soil datasets, climatic data, and discharge data to predict surface run-off and calibration purposes.

\section{Results And Discussion}

The percentage of live coral reefs in each observation station is presented in Fig. 2. Coral reef condition is determined based on the percentage of live coral cover consisting of hard corals (Acropora and nonAcropora). Criteria for assessing coral reef ecosystems' condition based on the percentage of coral cover [18].

Figure 2 shows that the average percentage of coral reef cover from 2014-2018 is in the fair category (< $50 \%$ ). The average percentage of coral reef cover from 2014 had a declining trend until 2017 and increased in 2018. Observations show that in 2014, coral reef cover in the good category (>50\%) occurred at stations 2 and 3 , and coral reef cover the smallest occurred in 2017 at station 1 with a poor category $(<$ $25 \%)$.

In the East Bintan Regional Marine Protected Area (KKLD), coral reefs are well developed and cover a very large area that can be found starting from Malang to Kijang Village. The width of the coral reef ranges from $100 \mathrm{~m}$ to $1000 \mathrm{~m}$. The total area of coral reefs located on the coast of East Bintan, including Manipur Island and the small islands around it, is $6,066.76$ ha [19]. It was found that 35 genera of stony coral with relatively different coral reef conditions [20].

Table 1

The land-use area from 2014-2018

\begin{tabular}{|llllll|}
\hline Land use & $\mathbf{2 0 1 4}$ & $\mathbf{2 0 1 5}$ & $\mathbf{2 0 1 6}$ & $\mathbf{2 0 1 7}$ & $\mathbf{2 0 1 8}$ \\
\cline { 2 - 7 } & & \multicolumn{5}{c|}{ (ha) } \\
\hline Plantation & 1.656 & 3.047 & 3.106 & 2.905 & 2.766 \\
\hline Settlement & 635 & 635 & 358 & 501 & 501 \\
\hline Bare Land & 114 & - & - & - & 205 \\
\hline Secondary Mangrove Forest & - & - & 46 & 42 & 42 \\
\hline Dryland Farming & 1.424 & 139 & 293 & 133 & 133 \\
\hline Shrubs & - & - & - & - & 139 \\
\hline Mixed Garden & 1.476 & 1.456 & 1.475 & 1.697 & 1.492 \\
\hline
\end{tabular}


The land use pattern for five years from 2014-2018 is presented in Table 1 and Fig. 3. In 2014, the widest land use pattern was for plantation (31\%), and the smallest was open land (2\%). Plantations' expansion occurred in a quite significant trend in 2015 , reaching $57 \%$ of the total area. However, the trend of plantation increased by 2\% in 2016 (59\%) and decreased in 2017 (55\%) and 2018 (52\%). The settlement land-use trends are fairly flat and do not experience a significant increase. The area of settlement in 2014 and 2015 was 12\%, decreasing in 2016 (7\%) and expanding in 2017 with the same area in $2018(9 \%)$. Area of dryland farming experienced a significant reduction from 2014. In 2014, the area for dryland farming was $27 \%$ and decreased to $3 \%$ in 2018. Land use for mixed gardens was evenly distributed every year (2014-2018) with insignificant fluctuation.

The modeling results using SWAT resulted in the highest soil loss in 2017, and the lowest was in 2015. The increasing trend occurred between 2015 to 2017 and decreased in 2018 (Table 2).

Table 2

Surface run-off, soil erosion dan sediment from 2014-2018

\begin{tabular}{|llllll|}
\hline Soil Loss & $\mathbf{2 0 1 4}$ & $\mathbf{2 0 1 5}$ & $\mathbf{2 0 1 6}$ & $\mathbf{2 0 1 7}$ & $\mathbf{2 0 1 8}$ \\
\hline Surface Runoff (mm/years) & 88.2 & 51.4 & 82.9 & 108.9 & 70.0 \\
\hline Soil Erosion (t/ha/year) & 4.3 & 3.5 & 5.1 & 6.8 & 3.8 \\
\hline Sediment (t/year) & $1,376.1$ & $1,111.7$ & $1,598.7$ & $2,115.3$ & $1,192.7$ \\
\hline
\end{tabular}

Rainfall, land use, and soil type greatly affect soil erosion on Bintan island's east coast. Based on Fig. 4, even though annual average rainfall variability appears to be the main driving force for the trend in surface run-off and soil erosion, other factors such as land use and management changes are also important. The soil loss is influenced by rainfall patterns, soil erodibility, slope factors, cropping systems, and management practices [21].

The analysis results of the effect of surface run-off, soil erosion, and sediment on hard coral reef cover over the five years (2014-2018) appear to have the same pattern. In general, the higher the surface runoff value, soil erosion, and sediment yields, the smaller the hard coral reef cover, as happened in 20152018. Surface run-off, soil erosion, and sediment were negatively correlated with hard coral reef cover. The correlation coefficient ( $r$ ) of each parameter from high to low is soil erosion > soil sediment > surface run-off (Table 3). 
Table 3

Correlation analysis results

\begin{tabular}{|lllll|}
\hline & Hard Coral Reef Cover & Surface Runoff & Soil Erosion & Soil Sediment \\
\hline Surface Runoff & 1 & & & \\
\hline Direct Runoff & -0.47 & 1 & & \\
\hline Soil Erosion & -0.72 & 0.91 & 1 & 1 \\
\hline Soil Sediment & -0.71 & 0.91 & 1.00 & 1 \\
\hline
\end{tabular}

The factor contribution translated into the coefficient of determination $\left(R^{2}\right)$ shows that the soil erosion factor is the most contributing factor to hard coral reef cover (52\%) (Fig. 5f), further soil sediment (50\%) and surface run-off (22\%). Other factors that affect coral reefs damage, including bleaching and low salinity of sea water [22].

The high average rainfall in 2017 (Fig. 4) caused a high incidence of soil loss and resulted in low hard coral reef cover in its year (Fig. $5 \mathrm{a}-\mathrm{C}$ ). The high rainfall and scanty vegetation cover lead to soil structure ravage and cause further the soil to be unable to store and absorb water during the rainy season, upsurge surface run-off, and impact increasing erosion rates. The erosion affects the environment, not limited to the on-site area, but can also extend to the off-site location. Soil erosion processes include the destruction of soil aggregates and the transport of sediments.

The Sediments generally settle at the bottom of the foothills, flooded areas, waterways, rivers, or coastal areas. In many regions, soil erosion affects soil quality, reducing soil nutrient content, with a consequent increase in food production costs [23], [24]. The heavy rains increased sediment time on reefs [25]. On the south Moloka'i coastal in Hawaii, 1-3 large rain events per year drove overland runoff and contributed $50 \%$ of the sediment on reefs $[26,27]$.

High values of surface run-off and soil erosion correlated with Orthic Acrisols soil type and cultivated land use. In the USDA soil taxonomy, Acrisols correspond to the Humult, Udult, and Ustult suborders of the Ultisols and Oxisols with a Kandic horizon. This soil has very low resilience to degradation and moderate sensitivity to yield decline. This soil is acid, base status $<50 \%$, and strong leaching. It's one of the most inherently infertile soils of the tropics and easily degraded chemically and organically very quickly when utilized. The estimated soil erosion rates were generally higher in cultivated areas of Orthic Acrisols than Vertic Cambisols and Gleyic Podzols soil types at slope steepness of over 35\%. Cambisols and Podzols soil types have high resilience to degradation, which corresponds to the soil erodibility value, which is smaller than Acrisols. Soils with low infiltration exhibited K-factors higher than 0.04 and were generally susceptible to soil erosion $[21,28]$. The decline in water quality and health of coral reefs will be accelerated by the process of land-use change on islands, which pedologically comes from erosive soil parent material with small and steep watershed systems [7]. 
Soil loss generation was high from cultivated lands due to the lack of conservation techniques. In east Bintan island, mixed garden, plantation, and bare land area with dense canopy cover contributed increasing of soil loss. Land-use changes from plantations to dryland farming and mixed gardens, as happened in the 2015-2016 period, also contributed to increased soil loss and decreased hard coral reef cover. Pollutants from agricultural land contribute at least $25 \%$ to coral reefs worldwide [29, 30]. An intensive agricultural system on erotic land will directly transmit sediment, inorganic, and organic nutrients to sedimentation in the estuary through aquifer systems, which eventually reach vulnerable reef ecosystems [31]. Forest conversion through extensive logging in the Solomon Islands resulted in the loss of 1587 ha of coral reef habitat and reduced the population of coastal Acroporid corals [32].

Sugarcane and pineapple plantations on the island of Maui, Hawaii, were the most significant drivers of coral reefs cover from coastal nitrogen flow from groundwater than other land uses [33]. The conversion of wetland (paddy) agriculture on Ishigaki Island, Japan, to sugarcane plantations in the 1980s led to a 2 ha decline in coral reefs cover over ten years [34]. Wetland farming (rice fields) can function as a sediment reservoir.

In the east coast, Bintan island, land-use changes from dry land farming to shrubs in the 2016-2018 period can reduce soil loss and increased hard coral reef cover. On the other hand, on Kuroshima island, Japan, a 10\% reduction in coral reefs cover was due to an increase in pasture land for livestock grazing during 1977-2005 [35]. Soil erosion increases as indicated by the decrease in vegetation cover, incompatibility between land use and its capability [36]. Land use for mining and settlement areas is very small on the east coast of Bintan island and may not affect increasing soil loss. Ex-mining land, such as that occurred in Papua New Guinea, causes a decrease in coral density, expansion, calcification of corals due to high levels of heavy metals $(\mathrm{Zn}$ and $\mathrm{Pb})$ on the reef even after mining has stopped [37]. The high population in the coastal area will increase feces or pathogenic fungi on the reef [38]. The existence of mangrove forests on the east coast of Bintan Island is very small. Even though mangrove populations have received considerable attention at the interface of coral reefs, if land-use systems on land encourage excessive erosion, the mangrove ecosystem will not function as a barrier to coral sedimentation [31].

Land cover plays a critical role in the soil erosion process because estimated soil erosion rates were low in areas covered with vegetation canopy regardless of slope gradients. The land vegetation landscape greatly influences the condition of the coral ecosystem on the coast. Land covered by dense vegetation will: (1) absorb rainwater and reduce freshwater input to coastal areas, (2) stabilize the soil to reduce surface run-off, riverbank erosion, and coastal sedimentation, (3) absorb and improve soil nutrients and heavy metal mineralization in soil and groundwater, and (4) providing a growing environment for habitats or other species that connect land and sea [39]. A land-based land conservation concept must build by inviting a series of socio-economic interests and stakeholders into the coastal area planning process [7].

\section{Conclusions}


The land use has been changed for five years (2014-2018) on the east coast of Bintan Island, and resulting in soil loss that varies each year. The average percentage of hard coral reef cover is in the fair category $(<50 \%)$. Rainfall, land use, and soil type greatly affect soil loss on east coast of Bintan island. Soil loss is generated from cultivated lands due to the lack of conservation techniques. In east coast of Bintan island, mixed garden, plantation, and bare land area with dense canopy cover contributed increasing of soil loss. Soil erosion is the biggest factor affecting hard coral reef cover, then sediment factors and surface run-off. The contribution of the soil loss factor to hard coral reef cover as a result of land use changes on the east coast of Bintan island is soil erosion (52\%), soil sediment $(50 \%)$ and surface run-off (22\%).

\section{Declarations}

\section{Availability of data and materials}

All data generated or analyzed during this study are derived from public resources and made available with the article

\section{Competing interests}

The authors declare they have no competing interests.

\section{Funding}

This work was supported by the Deputy of Earth Sciences of the Indonesian Institute of Sciences (COREMAP-ICT).

\section{Authors' contributions}

All authors read and approved the final manuscript.

\section{Acknowledgements}

The author would like to thank our colleagues who provided insight and expertise and helped clarify the ideas, and for technicians for their thoughtful assistance during the field study. We acknowledged comments from the reviewers and the editor.

\section{References}

1. Hoeksema BW. Delineation of the Indo-Malayan centre of maximum marine biodiversity: the Coral Triangle. In: Biogeography, time, and place: distributions, barriers, and islands. Springer; 2007. p. 117-178.

2. Burke L, WRI LS, Spalding M. Reefs at risk in Southeast Asia; 2002. 
3. Edinger EN, Limmon G V, Jompa J, Widjatmoko W, Heikoop JM, Risk MJ. Normal coral growth rates on dying reefs: are coral growth rates good indicators of reef health? Marine Pollution Bulletin. 2000; 40:404-425.

4. Erftemeijer PLA, Riegl B, Hoeksema BW, Todd PA. Environmental impacts of dredging and other sediment disturbances on corals: a review. Marine Pollution Bulletin. 2012; 64:1737-1765.

5. Margvelashvili N, Andrewartha J, Baird M, Herzfeld M, Jones E, Mongin M, Rizwi F, Robson BJ, Skerratt J, Wild-Allen K. Simulated fate of catchment-derived sediment on the Great Barrier Reef shelf. Marine Pollution Bulletin. 2018; 135:954-962.

6. Fabricius KE, Logan M, Weeks S, Brodie J. The effects of river run-off on water clarity across the central Great Barrier Reef. Marine Pollution Bulletin. 2014; 84:191-200.

7. Jupiter SD, Wenger A, Klein CJ, Albert S, Mangubhai S, Nelson J, Teneva L, Tulloch VJ, White AT, Watson JEM. Opportunities and constraints for implementing integrated land-sea management on islands. Environmental Conservation. 2017; 44:254-266.

8. Brodie J, Schroeder T, Rohde K, Faithful J, Masters B, Dekker A, Brando V, Maughan M. Dispersal of suspended sediments and nutrients in the Great Barrier Reef lagoon during river-discharge events: conclusions from satellite remote sensing and concurrent flood-plume sampling. Marine and Freshwater Research. 2010; 61:651-664.

9. Douglas I, Greer T, Bidin K, Spilsbury M. Impacts of rainforest logging on river systems and communities in Malaysia and Kalimantan. Global Ecology and Biogeography Letters. 1993; 245252.

10. Syakti AD, Idris F, Koenawan CJ, Asyhar R, Apriadi T. Biological pollution potential in the water of Bintan-Riau Islands Province, Indonesia: First appearance of harmful algal bloom species. The Egyptian Journal of Aquatic Research. 2019.

11. Lee S-W, Park G, Choi K-H. Biomass of plankton and macrobenthos and benthic species diversity in relation to environmental gradients in a nationwide coastal survey. Regional Studies in Marine Science. 2019; 26:100502.

12. Azizah D. Assessment of the environmental quality of Tanjungpinang Bay, Riau islands province. Dinamika Maritim. 2017; 6:47-53 [in Indonesian].

13. Halpern BS, Selkoe KA, White C, Albert S, Aswani S, Lauer M. Marine protected areas and resilience to sedimentation in the Solomon Islands. Coral Reefs 2013; 32:61-69.

14. Bégin C, Brooks G, Larson RA, Dragićević S, Scharrón CER, Côté IM. Increased sediment loads over coral reefs in Saint Lucia in relation to land use change in contributing watersheds. Ocean \& Coastal Management 2014; 95:35-45.

15. Kusnama, Sutisna, Amin, Koesoemadinata, Sukardi, Hermanto. Geological Map of Tanjungpinang Sheet, Sumatera. Geological Agency; 1994 [in Indonesian].

16. FAO. World reference base for soil resources 2014: international soil classification system for naming soils and creating legends for soil maps; 2015. 
17. Neitsch SL, Arnold JG, Kiniry JR, Williams JR, King KW. Soil and water assessment tool theoretical documentation version 2005. Grassland. Soil and Water Research Laboratory, Agricultural Research Service, Blackland Research Center, Texas Agricultural Experiment Station, Texas 2005.

18. Gomez ED, Yap HT. Monitoring reef condition. Coral Reef Management Handbook, UNESCO/ROSTSEA Edt By Kenchington RA, Hudson BT Jakarta 1988; 187-195.

19. CRITC- COREMAP II- LIPI. Coral reef information and training centre. Coral reef management program phase II-LIPI; 2007.

20. Adriman A, Purbayanto A, Budiharso S, Damar A. Effect of sedimentation on coral reefs in the marine conservation area of Bintan Timur, Riau Islands. Berkala Perikanan Terubuk. 2013; 41:90-101 [in Indonesian].

21. Wischmeier WH, Smith DD. Predicting rainfall erosion losses-a guide to conservation planning. USDA, Science and Education Administration; 1978.

22. Hadi TA, Abrar MG, Prayudha B, Johan O, Budiyanto A, Dzumalek AR, Alifatri LO, Sulha S, Suharsono. The status of Indonesian coral reefs 2019. Research Center for Oceanography (RCO); 2019.

23. Pimentel D, Harvey C, Resosudarmo P, Sinclair K, Kurz D, McNair M, Crist S, Shpritz L, Fitton L, Saffouri R. Environmental and economic costs of soil erosion and conservation benefits. Science. $1995 ; 267: 1117-1123$.

24. Lal. Soil erosion impact on agronomic productivity and environment quality. Critical Reviews in Plant Sciences. 1998; 17:319-464.

25. Draut AE, Bothner MH, Field ME, Reynolds RL, Cochran SA, Logan JB, Storlazzi CD, Berg CJ. Supply and dispersal of flood sediment from a steep, tropical watershed: Hanalei Bay, Kaua'i, Hawai'i, USA. Geological Society of America Bulletin. 2009; 121:574-585.

26. Risk MJ. Assessing the effects of sediments and nutrients on coral reefs. Current Opinion in Environmental Sustainability. 2014; 7:108-117.

27. Tribble G, Stock J, Jacobi J. Watershed processes from ridge to reef: consequences of feral ungulates for coral reef and effects of watershed management. In: Stringer, Christina E; Krauss, Ken W; Latimer, James S, Eds 2016 Headwaters to Estuaries: Advances in Watershed Science and Management-Proceedings of the Fifth Interagency Conference on Research in the Watersheds March 2-5, 2015, North Charleston, South Carolina E-General Technical Report SRS-211 Asheville, NC: US Department of Agriculture Forest Service, Southern Research Station 302 P. 2016; 211:194.

28. Cassel DK, Lal R. Soil physical properties of the tropics: common beliefs and management restraints. Myths and Science of Soils of the Tropics 1992; 61-89.

29. Burke L, Reytar K, Spalding M, Perry A. Reefs at risk revisited. World Resources Institute; 2011.

30. Kroon FJ, Schaffelke B, Bartley R. Informing policy to protect coastal coral reefs: Insight from a global review of reducing agricultural pollution to coastal ecosystems. Marine Pollution Bulletin. 2014; 85:33-41.

31. Carlson RR, Foo SA, Asner GP. Land use impacts on coral reef health: a ridge-to-reef perspective. Frontiers in Marine Science. 2019; 6:562. 
32. Hamilton RJ, Almany GR, Brown CJ, Pita J, Peterson NA, Choat JH. Logging degrades nursery habitat for an iconic coral reef fish. Biological Conservation. 2017; 210:273-280.

33. Bishop JM, Glenn CR, Amato DW, Dulai H. Effect of land use and groundwater flow path on submarine groundwater discharge nutrient flux. Journal of Hydrology: Regional Studies. 2017; 11:194-218.

34. Yamano $\mathrm{H}$, Watanabe $\mathrm{T}$. Coupling remote sensing and coral annual band data to investigate the history of catchment land use and coral reef status. In: Coral Reef Science. Springer; 2016. p. 47-53.

35. Dadhich AP, Nadaoka K, Motomura Y, Watanabe A. Potential impacts of land use change dynamics and submarine groundwater discharge on fringing reefs of Kuroshima Island, Japan. Journal of Coastal Conservation. 2017; 21:245-254.

36. Herrick JE, Neff J, Quandt A, Salley S, Maynard J, Ganguli A, Bestelmeyer B. Prioritizing land for investments based on short-and long-term land potential and degradation risk: A strategic approach. Environmental Science and Policy. 2019; 96:52-58.

37. Fallon SJ, White JC, McCulloch MT. Porites corals as recorders of mining and environmental impacts: Misima Island, Papua New Guinea. Geochimica et Cosmochimica Acta. 2002; 66:45-62.

38. Norat-Ramírez J, Méndez-Lázaro P, Hernández-Delgado EA, Mattei-Torres H, Cordero-Rivera L. A septic waste index model to measure the impact of septic tanks on coastal water quality and coral reef communities in Rincon, Puerto Rico. Ocean and Coastal Management. 2019; 169:201-213.

39. Hefting MM, Clement J-C, Bienkowski P, Dowrick D, Guenat C, Butturini A, Topa S, Pinay G, Verhoeven JTA. The role of vegetation and litter in the nitrogen dynamics of riparian buffer zones in Europe. Ecological Engineering. 2005; 24:465-482.

\section{Figures}




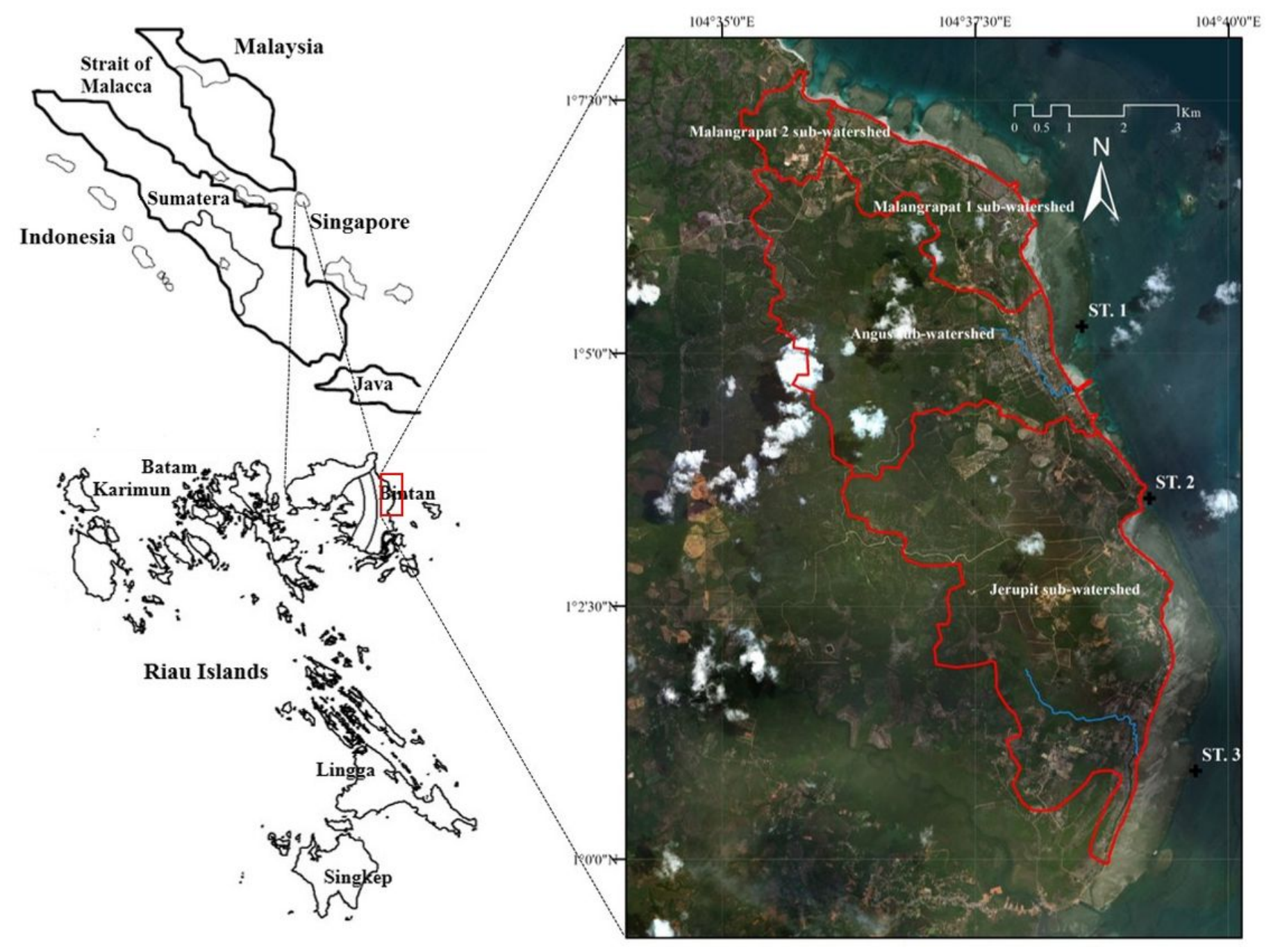

\section{Figure 1}

The study location in East Coastal of Bintan island. Note: The designations employed and the presentation of the material on this map do not imply the expression of any opinion whatsoever on the part of Research Square concerning the legal status of any country, territory, city or area or of its authorities, or concerning the delimitation of its frontiers or boundaries. This map has been provided by the authors. 


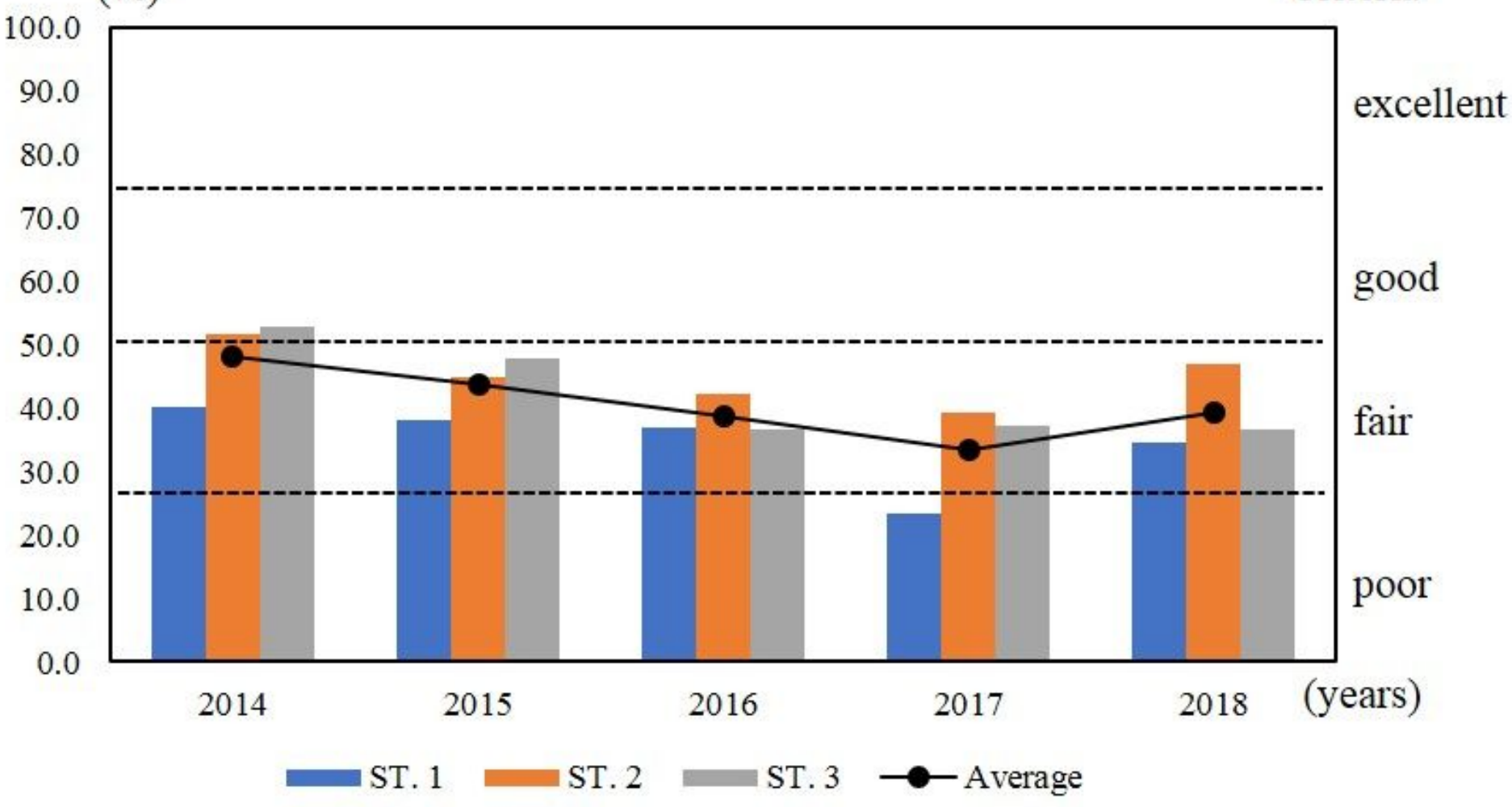

Figure 2

The condition of hard coral reef cover in 2014-2018

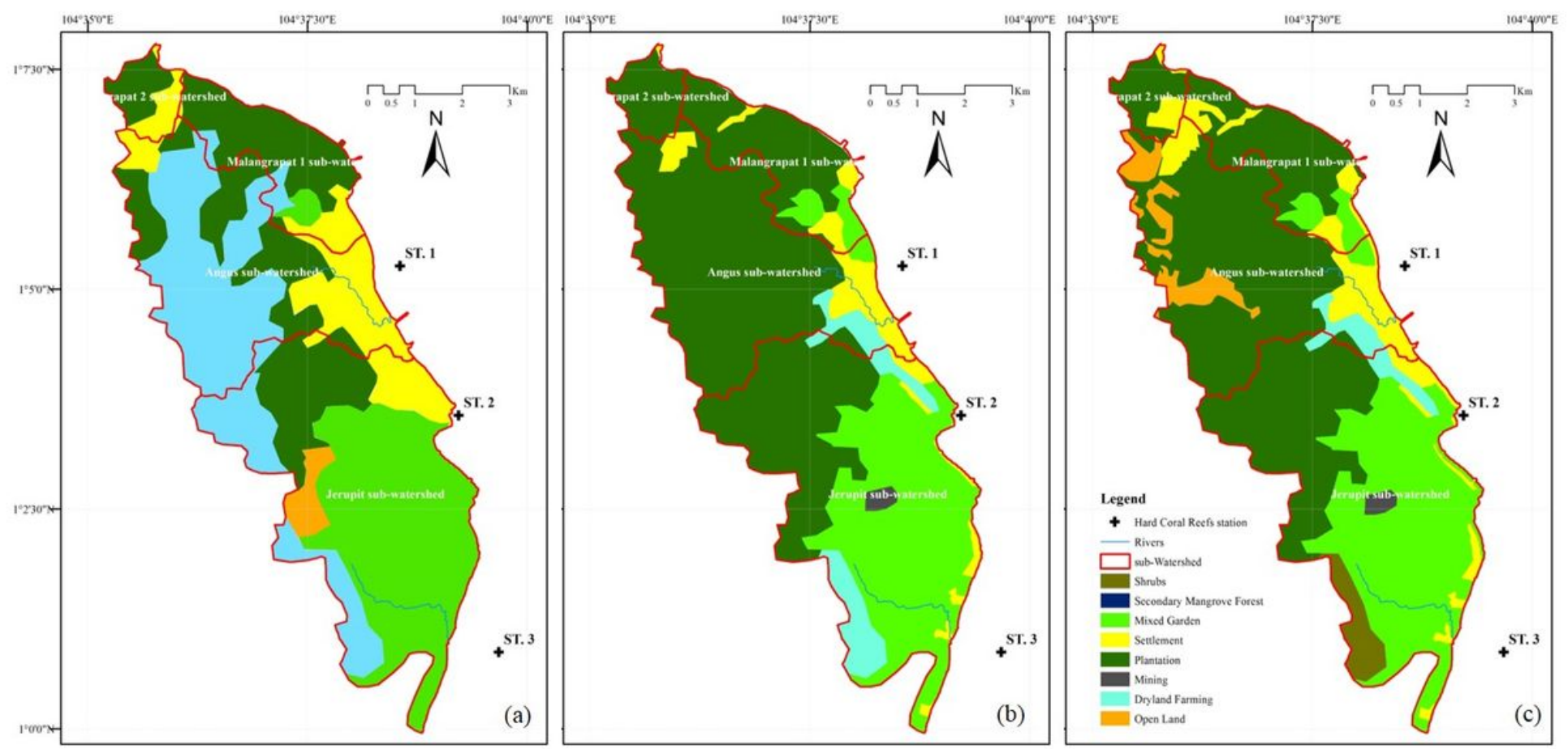

Figure 3 
Land use map in 2014 (a), 2016 (b), and 2018 (c) Note: The designations employed and the presentation of the material on this map do not imply the expression of any opinion whatsoever on the part of Research Square concerning the legal status of any country, territory, city or area or of its authorities, or concerning the delimitation of its frontiers or boundaries. This map has been provided by the authors.

Rainfall (mm) Surface Runoff (mm)

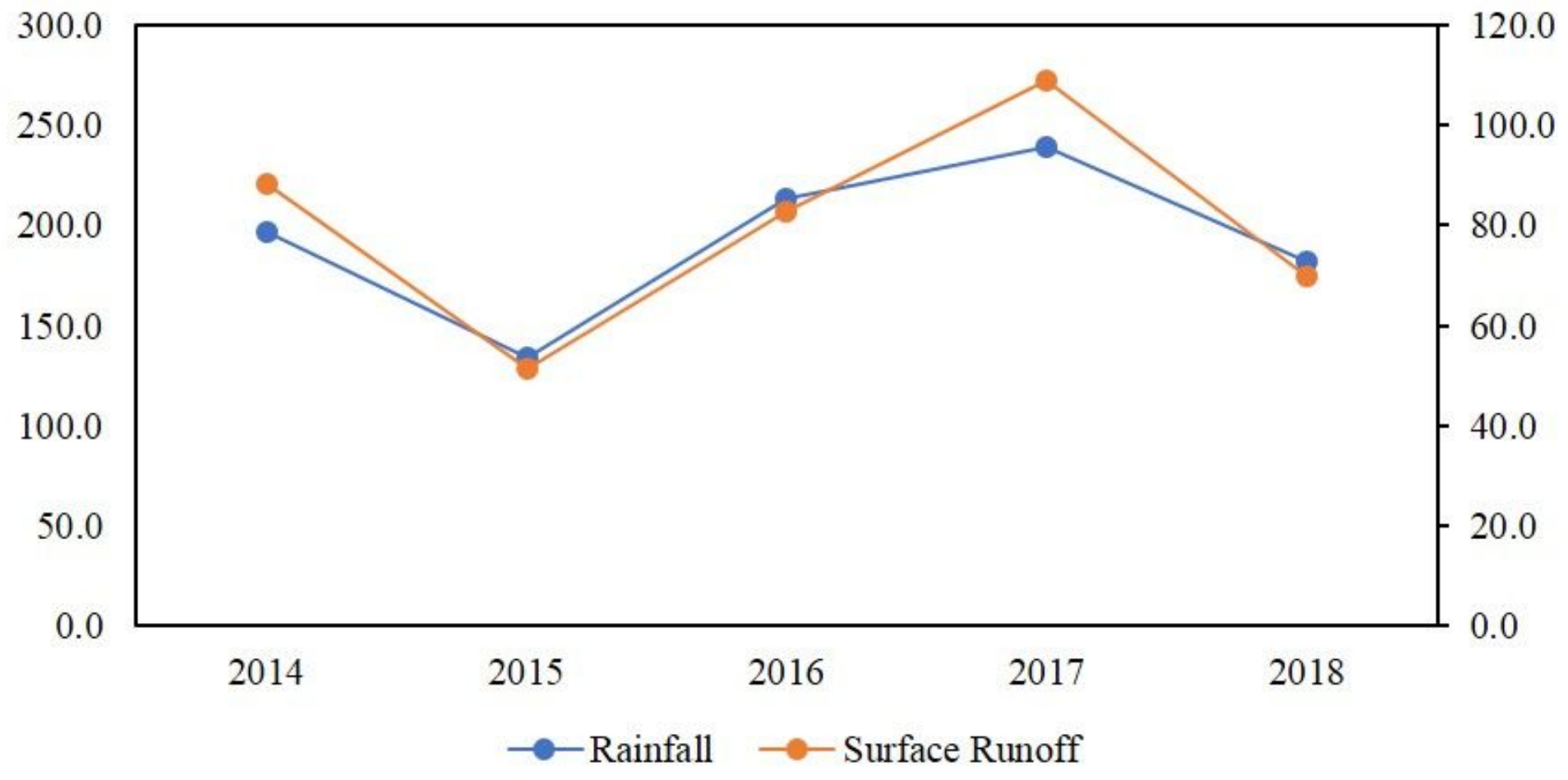

Figure 4

Average surface run-off and rainfall in 2014-2018
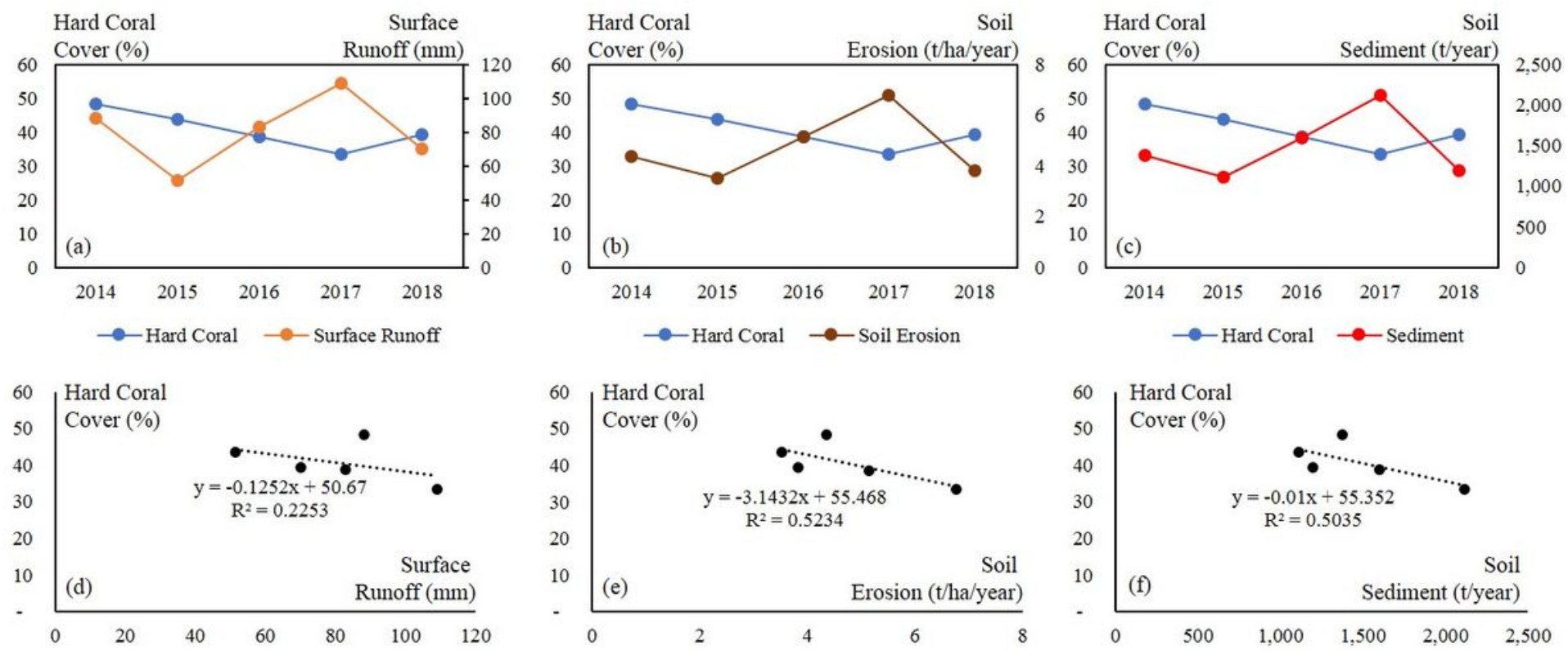
Trend and relationship between hard coral reef cover with soil loss in 2014-2018 